\title{
Argo Float Reveals Biogeochemical Characteristics Along the Freshwater Gradient Off Western Patagonia
}

\section{OPEN ACCESS}

Edited by:

Eduardo Joel Quiroga Jamett, Pontifical Catholic University of Valparaíso, Chile

Reviewed by: Fabrizio D'Ortenzio, Centre National de la Recherche Scientifique (CNRS), France Stephen C. Riser, University of Washington, United States

*Correspondence: Gonzalo S. Saldías gsaldias@ubiobio.cl

Specialty section: This article was submitted to Marine Biogeochemistry, a section of the journal Frontiers in Marine Science

Received: 01 October 2020 Accepted: 01 June 2021 Published: 09 July 2021

Citation:

Galán A, Saldías GS, Corredor-Acosta A, Muñoz R, Lara C and Iriarte JL (2021) Argo Float Reveals Biogeochemical Characteristics Along the Freshwater Gradient Off Western Patagonia.

Front. Mar. Sci. 8:613265. doi: 10.3389/fmars.2021.613265

\begin{abstract}
Alexander Galán ${ }^{1}$, Gonzalo S. Saldías ${ }^{2,3 *}$, Andrea Corredor-Acosta ${ }^{3}$, Richard Muñoz ${ }^{2}$, Carlos Lara ${ }^{4,5}$ and José Luis Iriarte ${ }^{3,6,7}$

${ }^{1}$ Centro de Investigación de Estudios Avanzados del Maule (CIEAM), Vicerrectoría de Investigación y Postgrado \& Departamento de Obras Civiles, Facultad de Ciencias de la Ingeniería, Universidad Católica del Maule, Talca, Chile, ${ }^{2}$ Departamento de Física, Facultad de Ciencias, Universidad del Bío-Bío, Concepción, Chile, ${ }^{3}$ Centro FONDAP de Investigación en Dinámica de Ecosistemas Marinos de Altas Latitudes (IDEAL), Valdivia, Chile, ${ }^{4}$ Departamento de Ecología, Facultad de Ciencias, Universidad Católica de la Santísima Concepción, Concepción, Chile, ${ }^{5}$ Centro de Investigación en Recursos Naturales y Sustentabilidad (CIRENYS), Universidad Bernardo O'Higgins, Santiago, Chile, ${ }^{6}$ Instituto de Acuicultura, Universidad Austral de Chile, Puerto Montt, Chile, ${ }^{7}$ Centro de Investigación Oceanográfica COPAS Sur-Austral, Universidad de Concepción, Concepción, Chile
\end{abstract}

The coastal region off Chilean Patagonia has been poorly studied due to the lack of available observations. Here we analyzed, by the very first time, biogeochemical (BGC) data to elucidate the role that biological and physical processes play on nitrate, oxygen, $\mathrm{pH}$ and hydrographic variables, along a salinity gradient off central Patagonia. Argo float profiles covering the upper ocean from December 2015 to July 2019 reveal that offshore waters are characterized by low temperatures and high salinities related to high oxygen and medium-high values of $\mathrm{pH}$ and nitrate. As the Argo float drifted onshore, freshwater influences the upper 50-100 m with low salinity and high temperature. Waters under the influence of the continental runoff were characterized by medium-to-high oxygen and $\mathrm{pH}$ levels, and the lowest nitrate concentrations. Interestingly, oxygen-deficient waters located beneath the freshwater-modified layer showed the lowest $\mathrm{pH}$ and highest nitrate. A comprehensive analysis of the temporal and vertical variability of the oxygen:nitrate ratio, in conjunction with biological-related and physical parameters, indicates that the $B G C$ variability seems to be the result of a synergistic interaction between physical and biological processes, where the stratification sets up the environment and promotes the biological response that, in turn, is auto-regulated by modifying the chemical composition in the freshwater-influenced zone. The arrival of future floats with additional sensors (Chlorophyll/Fluorescence, Photosynthetically Active Radiation, Backscatter, etc.) will add new BGC properties that improve our understanding of the coastal marine response to the increasing freshwater input off western Patagonia in the context of climate change.

Keywords: stratification, Patagonian ice fields, Argo floats, HYCOM, freshening, biogeochemical processes, Redfield ratio

\section{INTRODUCTION}

Ocean biogeochemistry (BGC) has been frequently studied in particular regions, commonly associated with long-term monitoring programs. The lack of a global observational array of BGC parameters has led to the recent development of autonomous platforms, such as Argo floats, to measure nutrients, dissolved oxygen, and bio-optical properties 
(Gould et al., 2004; Claustre et al., 2020). The Argo network comprises a global array of more than 4,000 free-drifting and battery-powered profiling floats measuring temperature, salinity, oxygen, nitrate, and $\mathrm{pH}$ from the surface to about 2,000 m depth (Riser et al., 2016; Claustre et al., 2020). However, only $<10 \%$ of the floats are equipped with sensors other than temperature and salinity. The BGC-Argo program is transforming our understanding of ocean variability over regional (e.g., Mediterranean Sea) and basin-scale efforts (e.g., SOCCOM; Southern Ocean Carbon and Climate Observations and Modeling) relying heavily on BGC-Argo measurements (Roemmich et al., 2019). The use of BGC-Argo floats has helped to increase the understanding of key bio-physical processes in the upper ocean, including (i) the initiation of spring phytoplankton blooms occurring prior to a significant shoaling of the mixed layer in the western North Atlantic (Boss and Behrenfeld, 2010), (ii) the development of new parameterizations to monitoring $\mathrm{CO}_{2}$ in the subarctic North Pacific (Li et al., 2019), (iii) the temporal coupling between physical and biological properties with the development of the seasonal pycnocline in the western North Pacific (Sukigara et al., 2011), and (iv) a significant $\mathrm{CO}_{2}$ outgassing in the high-latitude Southern Ocean linked to the upwelling of deep water (Gray et al., 2018), among others.

The freshwater input into the coastal ocean is one of the leading causes of sea-level rise and coastal stratification (Munk, 2003). In general, the melting of Greenland and Antarctic ice sheets is the primary source of freshwater impacting significantly sea-level rise (Vizcaíno et al., 2008; Nerem et al., 2018; Adusumilli et al., 2020). Off western Patagonia, the Subantarctic Water (SAAW) is mixed with freshwater from river outflows, rain, and ice melting, generating Modified Subantarctic Waters (MSAAW) (Sievers and Silva, 2008; Saldías et al., 2019). Recently, the first study analyzing the freshwater structure and seasonal variability off western Patagonia showed that the largest freshwater content is centered off central Patagonia next to the Gulf of Penas, where the low-salinity surface layer dominates the stratification of the upper ocean. In contrast, the freshwater content plays a minor role in setting up the stratification off northern and southern Patagonia (Saldías et al., 2019). The BGC properties of the coastal ocean off western Patagonia has been largely overlooked due to the lack of continuous field campaigns. In comparison, most efforts have been focused in fjords and channels along the entire Chilean Patagonia (Pantoja et al., 2011; Iriarte et al., 2014, and references therein). To the best of our knowledge, this is the first study reporting BGC variability in the coastal ocean off the Gulf of Penas in central Patagonia, a region influenced by freshwater from rivers and melting from the two major Patagonian icefields.

The local stratification, product of a strong thermohaline interaction between the runoff of continental waters with the SAAW at the Chilean Patagonia fjords $\left(41-53^{\circ} \mathrm{S}\right.$ ) (Dávila et al., 2002; Iriarte et al., 2014; Saldías et al., 2019), has an important effect on the phytoplankton dynamics (i.e., distribution and activity) (González et al., 2013; Iriarte et al., 2014; Jacob et al., 2014; León-Muñoz et al., 2018) since stratification keeps phytoplankton cells within the euphotic zone by limiting the depth of turbulent mixing. Nevertheless, stratification also leads to the eventual cessation of primary production after phytoplankton blooms, owing to the reduction in the vertical supply of macronutrients from subsurface waters (Iriarte et al., 2007, 2014). However, little is known about the phytoplankton response to freshwater-influenced stratification in the coastal region, further considering that inorganic nutrients availability should present a marked seasonality related mainly with the intrusion of nutrient-poor waters (except for silicic acid); modulated mainly by the pluvial (autumn-winter) and snowmelt (spring) Patagonian seasonal regimes (Iriarte et al., 2017, and references therein). In this intricate scenario, we study the spatiotemporal BGC variability to understand the role of biological (e.g., primary production or respiration) and physical (e.g., water column stratification or air-sea interaction) processes on the recorded BGC measurements, and propose that stratification triggers the biological response, which, in turn, modulates the elemental variability (i.e., consume vs. production) of the coastal system off central Patagonia.

\section{MATERIALS AND METHODS}

We used profiles of temperature, salinity, pressure, oxygen, $\mathrm{pH}$, and nitrate from a BGC Argo profiling float (5904663) during December 2015-July 2019 (see Figure 1). Only good qualitycontrolled data were used, and thus, $\mathrm{pH}$ data from December 2019 were not considered (see Figure 2d) since their values increased sharply to ranges over 25 . We have only used flag $n=1$ "Good Data" according to the section 3.2 Reference table 2: Argo quality control flag scale (Argo user's manual). Unfortunately, the 5904663 float did not have PAR (Photosynthetic Active Radiation), chlorophyll, and backscatter sensors to complement the BGC measurements. Argo floats are programmed to descend to a parking depth ranging from 1,000 to $2,000 \mathrm{~m}$. At this depth they drift with the flow field for $\sim 10$ days, after which they ascend to the surface recording the specified variables in a continuous profile (Roemmich et al., 2009; Wong et al., 2020). The 5904663 float recorded data to a depth of $2,000 \mathrm{~m}$. However, a lowresolution sampling interval of $\sim 100 \mathrm{~m}$ was programmed below $1,000 \mathrm{~m}$. The higher vertical resolution is $\sim 1 \mathrm{~m}$ in the top $100 \mathrm{~m}$. Here, our focus is on the BGC variability in the upper ocean by which the top $500 \mathrm{~m}$ are analyzed.

Maps of surface salinity were obtained from the HYbrid Coordinate Ocean Model (HYCOM) with a spatial resolution of $1 / 12^{\circ}$ (https://www.hycom.org/dataserver/gofs-3pt0/analysis/) for two contrasting freshwater conditions on March 25 and August 16, 2018 (see Figure 1). HYCOM uses isopycnal coordinates in the open ocean, terrain-following coordinates in shallow coastal regions, and z-level coordinates in the mixed layer, thus being optimal for large domains with variable topography and ocean conditions (Bleck and Boudra, 1981; Bleck, 2002). A T-S diagram and time series of concomitant surface temperature and salinity data reveal a high correlation in temperature $(R=0.97)$ and a fairly acceptable correlation in salinity $(R=0.65)$ between the surface HYCOM and Argo float data (Supplementary Figure 1).

A time series of surface total Chlorophyll-a (Chl-a) was obtained from monthly satellite data from version 4.2 of the 

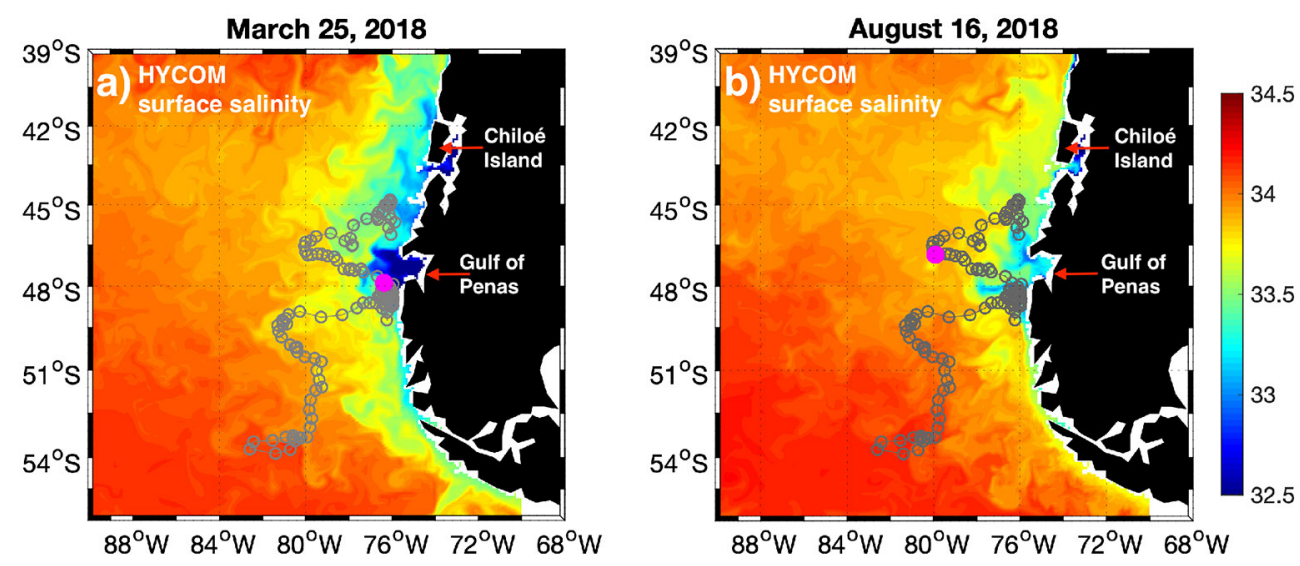

FIGURE 1 | Maps of surface salinity from HYCOM global model on (a) March 25, 2018, and (b) August 16, 2018. The gray circles denote the trajectory of BGC Argo float 5904663 from December 8, 2015 (offshore, southwest limit) to July 3, 2019 (nearshore, north of Gulf of Penas). The magenta dot shows the location of the float on the same date of the corresponding HYCOM salinity field.

Ocean Color Climate Change Initiative (OC-CCI, a merged product available at http://www.oceancolour.org/), at processing level 3 and spatial resolution of $4 \mathrm{~km}$. To obtain the Chl-a values around the location of the BGC-Argo float, a nine-pixel window centered in the location of the BGC-Argo float was used at each time step. Only match-ups with a coefficient of variation $<0.15$ and $50 \%$ of valid data in the window were considered. Then, the median Chl-a concentration of these pixels was taken as the total Chl-a estimate (Corredor-Acosta et al., 2018). The blank spaces in the Chl-a time series correspond to missing data (i.e., months in which the criteria were not met).

The stability of the water column, was quantified through the Potential Energy Anomaly (PEA) following Saldías et al. (2019). The PEA is the amount of mechanical energy required to instantaneously mix the water column (Simpson et al., 1981). Therefore, a highly stratified water column would require more energy to become homogenized. To characterize the stratification of the water column across the zonal gradient (offshore-onshore) along the trajectory of the BGC-Argo float, the PEA was evaluated for the entire upper ocean (500 m depth) and for the first 250 $\mathrm{m}$ of depth, where the greatest changes in physical and chemical properties were observed.

\section{RESULTS}

The coastal ocean off western Patagonia has a low-salinity band along its entire latitudinal extension. The major freshwater content comes from the Gulf of Penas in central Patagonia (Figures 1a,b). The BGC Argo float 5904663 was deployed on the southwestern tip of its trajectory $\left(\sim 54^{\circ} \mathrm{S}-83^{\circ} \mathrm{W}\right)$ on December 2015 and drifted in the north and northeast direction. By about April 2017 the float reached the coastal region south of the Gulf of Penas and stayed looping around until April 2018, before continuing farther north (Figure 1; gray trajectory). The contrast in freshwater conditions between the examples of March 25 and August 16, 2018 is remarkable, with the float being profiling the region next to the mouth of the Gulf of Penas (a magenta dot in Figure 1 denotes the position of the float) during a high freshwater outflow event (Figure 1a), and being drifted farther offshore when the freshwater content was considerably reduced in winter (Figure 1b).

The vertical structure of the upper $500 \mathrm{~m}$ along the path of sampling is shown in Figure 2. During most of 2016 the float measured the vertical structure and BGC variability in offshore waters. Low temperatures $\left(<8^{\circ} \mathrm{C}\right)$, high salinity (generally $>34$ ), high oxygen $\left(>250 \mu \mathrm{mol} \mathrm{kg}{ }^{-1}\right)$, and mediumto-high values of $\mathrm{pH}$ (about 7.9-8.1) and Nitrate (about 20$25 \mu \mathrm{mol} \mathrm{kg} \mathrm{kg}^{-1}$ ) characterized the upper ocean of offshore waters (Figures 2a-e). A low-salinity buoyant layer frequently influenced the profiles near the Guf of Penas in the top 50-100 m during most of 2017 and early 2018 (Figure 2b). This freshwater layer was characterized, relative to periods with higher surface salinity such as June-December 2018, by high temperature $\left(>11^{\circ} \mathrm{C}\right)$, high oxygen $(>250 \mu \mathrm{mol}$ $\left.\mathrm{kg}^{-1}\right)$ and $\mathrm{pH}(>8)$, and low nitrate $\left(<15 \mu \mathrm{mol} \mathrm{kg}^{-1}\right)$ concentrations (Figures 2a-e). This pattern was repeated during the following freshening event in spring-summer 2018-2019. A sharp vertical gradient in BGC properties was found below the surface low-salinity layer with low-oxygen, low-pH, and high-nitrate waters. Note that the depth of the base of this subsurface layer fluctuated around 200-450 m (Figures 2a-e), and that low-pH $(<7.8)$ and high-nitrate $\left(>28 \mu \mathrm{mol} \mathrm{kg}{ }^{-1}\right)$ intermediate waters were restricted to the pools of low oxygen $\left(<180 \mu \mathrm{mol} \mathrm{kg}^{-1}\right)$.

Vertical profiles of hydrographic (temperature, salinity, and potential density) and BGC (oxygen, $\mathrm{pH}$, and nitrate) variables during contrasting freshwater conditions (same as in Figure 1) are presented in Figure 3. Elevated freshwater conditions with a low salinity layer occupied the top $50 \mathrm{~m}$ of the water column (Figure 3B). Low salinity and high temperature contributed to a low-density buoyant upper layer that only reached a higher density as in the farther offshore profile at $100 \mathrm{~m}$ 

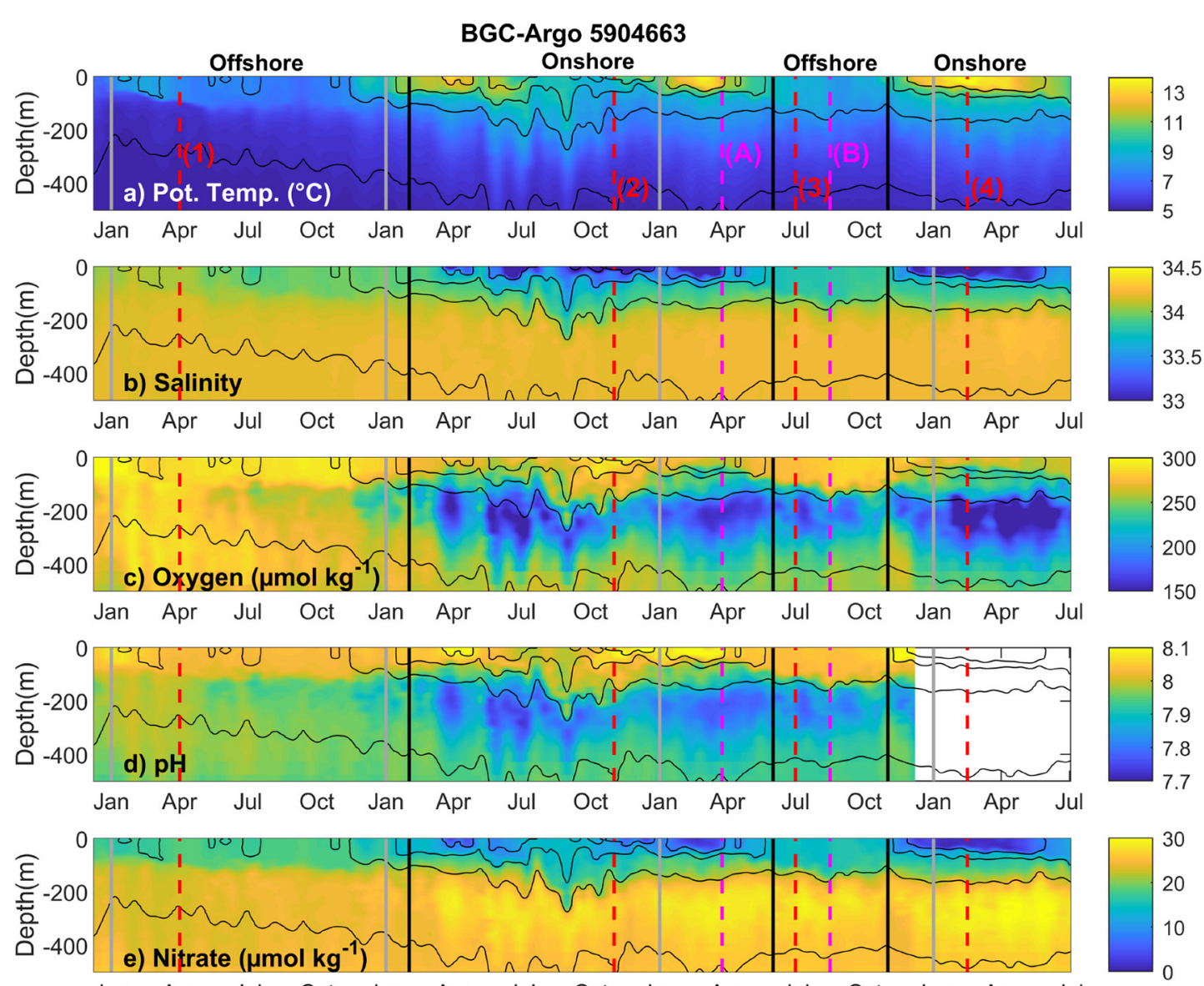

Jan Apr Jul Oct Jan Apr Jul Oct Jan Apr Jul Oct Jan Apr Jul
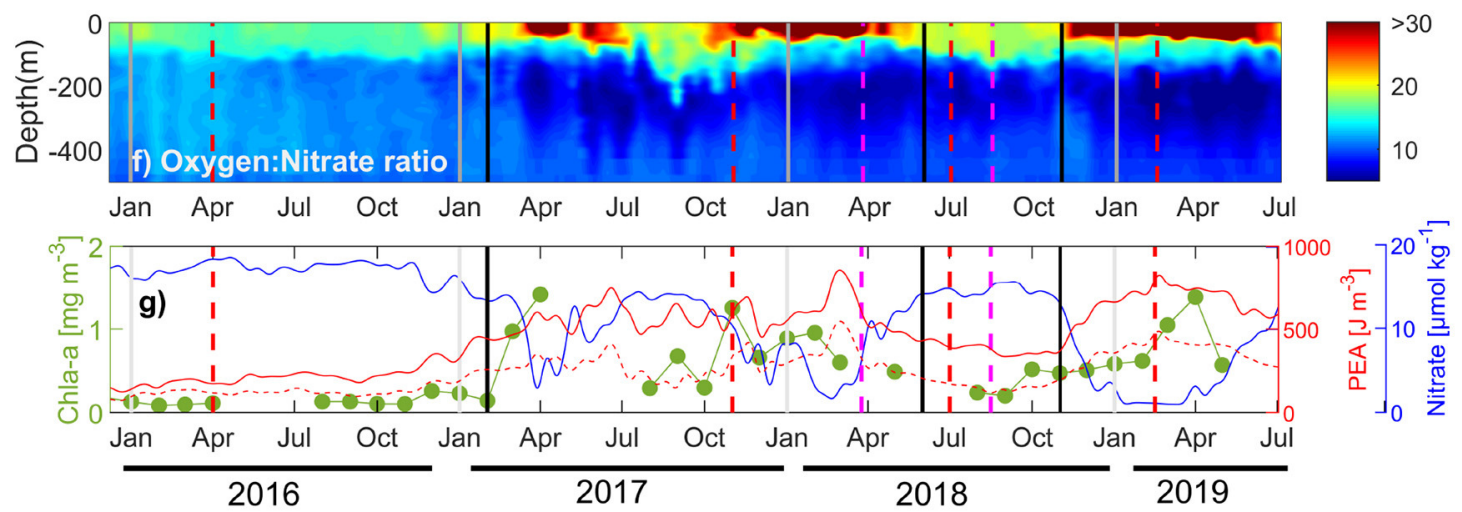

FIGURE 2 | Evolution of the upper ocean (top 500 m) (a) potential temperature, (b) salinity, (c) oxygen, (d) pH, (e) Nitrate, (f) Oxygen:Nitrate ratio, (g) surface Chlorophyll-a (Chl-a; green line), Potential Energy Anomaly (PEA) for the upper $250 \mathrm{~m}$ (solid red line) and $500 \mathrm{~m}$ (dashed red line), and surface nitrate (1 m depth; blue line), along the trajectory of BGC-Argo float 5904663 from December 2015 to July 2019. Black contours denote isopycnals. Vertical red lines indicate the dates of selected T-S diagrams shown in Figure 4. Vertical magenta lines correspond to the dates of the two HYCOM salinity maps shown in Figure 1a (March 25, 2018) and Figure 1b (August 16, 2018). Vertical black lines indicate the transition from offshore to onshore (and vice versa) and gray lines denote the beginning of each year. The Oxygen:Nitrate ratio is shown between 5 and 30 (range that contain the $96.9 \%$ of the data) to facilitate the interpretation. The ratio is presented in positive values (it has been multiplied by -1 with respect to the Redfield ratio).

depth (Figure 3C) - the density structure of both profiles were practically identical below $100 \mathrm{~m}$. BGC properties were very different on both dates, not only in the top layer but also at deeper levels. In general, oxygen and $\mathrm{pH}$ (nitrate) concentrations were considerably (slightly) lower (higher) on March 25 than August 16, 2018 when high freshwater conditions existed off the Gulf of Penas (Figures 3D-F). However, pH increased whereas nitrate concentration decreased in the low-salinity (top $50 \mathrm{~m}$ ) upper 

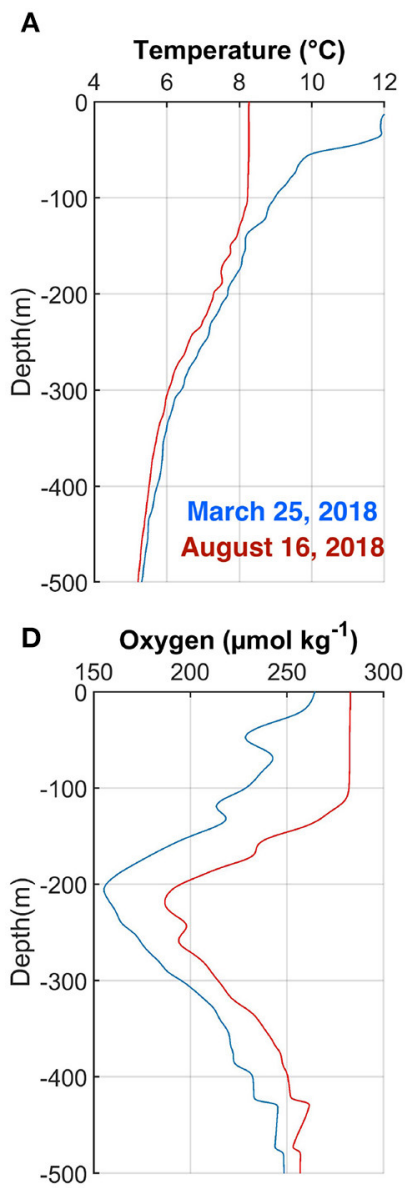

B

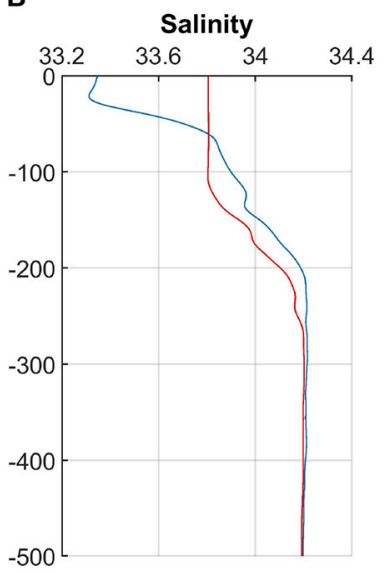

E

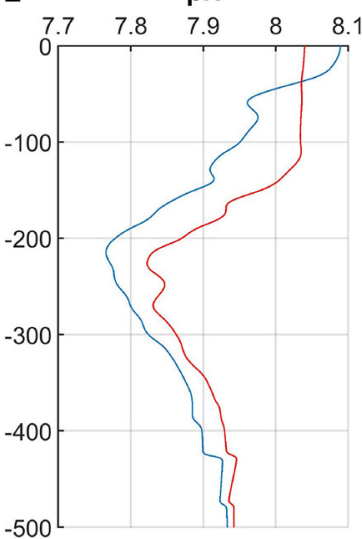

C Density $\left(\mathrm{kg} \mathrm{m}^{-3}\right)$

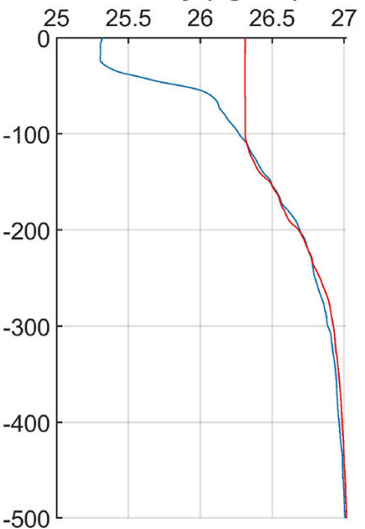

F $\quad$ Nitrate $\left(\mu \mathrm{mol} \mathrm{kg}{ }^{-1}\right)$

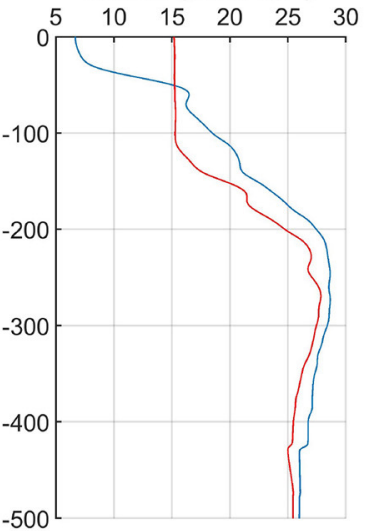

FIGURE 3 | Vertical profiles of (A) Temperature, (B) Salinity, (C) Potential density, (D) Oxygen, (E) pH, and (F) Nitrate on March 25 (blue curves) and August 16 (red curves), 2018 (see Figure 1).

layer (Figures 3E,F; blue curves), which is coherent with the BGC characteristics of meltwater from nearby glaciers.

The stoichiometric ratio proposed by Redfield (1934) established that, in average, marine organic matter and the required oxygen consumption keeps the following elemental proportion: $106 \mathrm{C}: 16 \mathrm{~N}: 1 \mathrm{P}:-138 \mathrm{O}_{2}$. Taking into account the variability of the Readfield ratio in the global ocean (Anderson, 1995; Lenton and Watson, 2000; Karl et al., 2001; Klausmeier et al., 2004), the stoichiometric proportion regarding to oxygen and nitrate should fluctuate between 8.6 and 10.6, considering that the oxygen coefficient could oscillate between -138 and -170 (Anderson, 1995; Johnson, 2010). The spatiotemporal variability of the oxygen and nitrate $\left(\mathrm{O}_{2}: \mathrm{NO}_{3}^{-}\right)$ ratio (Figure 2f) was used to assess the linkages between the cycling of these elements relative to the Redfield proportion and to elucidate which processes, biological (i.e., primary production or respiration) or physical (i.e., water column stratification, horizontal transport, and/or air-sea interaction), are the main modulators of the elemental signal registered. Much of the vertical variability in the $\mathrm{O}_{2}: \mathrm{NO}_{3}^{-}$ratio occurred onshore, with maximum values $(>30)$ coinciding with events of high Chl-a (Figure 2g), and conditions of marked water column stratification (evidenced by elevated PEA; Figure 2g) associated to the high freshwater content off Gulf of Penas. This freshwater runoff produces sharp horizontal and vertical salinity gradients (Figures 1, 2b) in the coastal zone. In contrast, subsurface waters beneath this freshwater layer, particularly between 150 and $300 \mathrm{~m}$ depth, showed the lower $\mathrm{O}_{2}: \mathrm{NO}_{3}^{-}$ratio $(\sim 5.0)$ throughout the float path and relative to the expected Redfield stoichiometry (8.6-10.6). Farther offshore, away from the freshwater influence, differences in $\mathrm{O}_{2}: \mathrm{NO}_{3}^{-}$ratio between surface $(\sim 15)$ and subsurface waters $(\sim 10)$ are less pronounced and, below the mixed layer, somewhat closer to the expected Redfield model.

\section{DISCUSSION}

BGC-Argo floats are key platforms for the study of coastal systems characterized by high terrestrial input of carbon and nutrients, which could promote short-term fluctuations in primary productivity and oxygen levels, changes in $\mathrm{pH}$, 

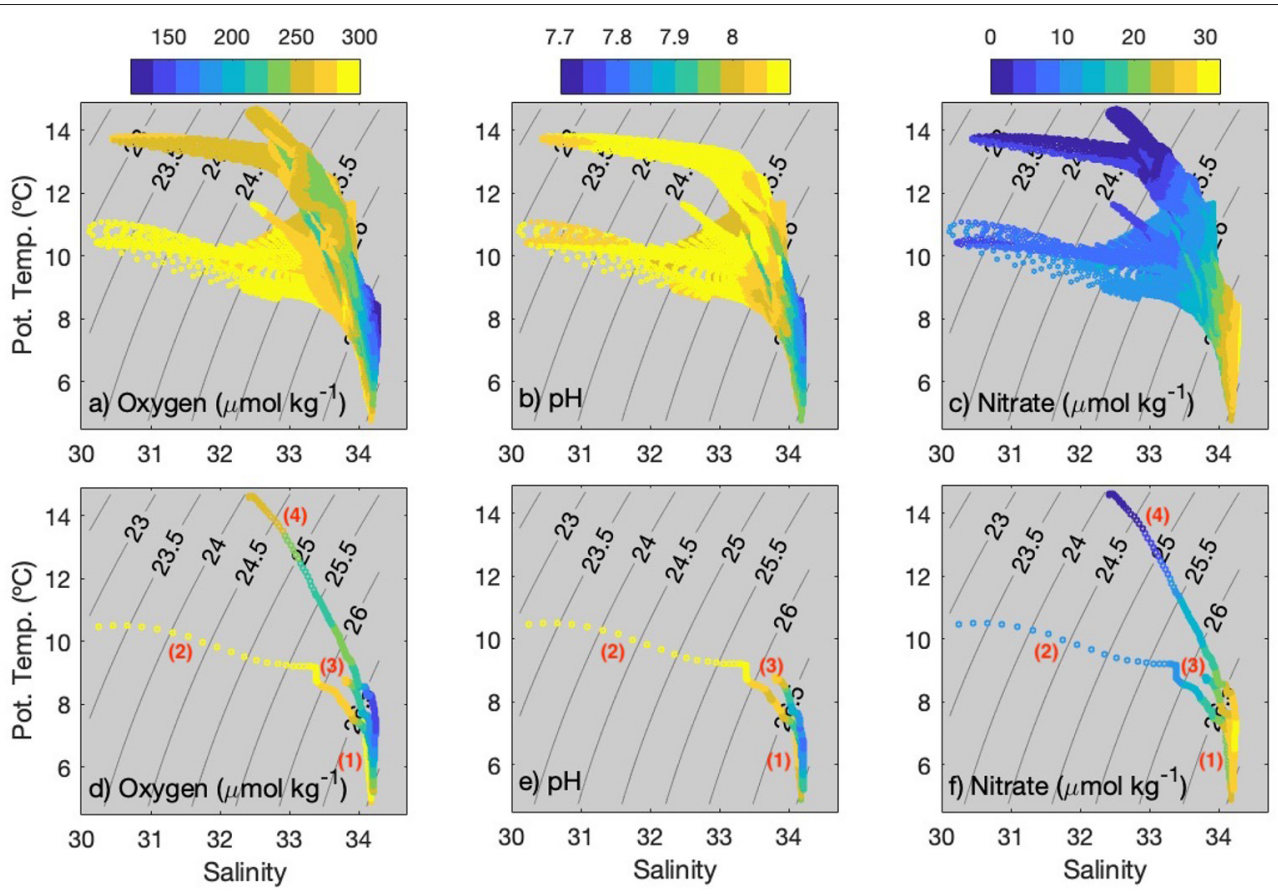

FIGURE 4 | T-S diagrams with values of $\mathbf{( a , d )}$ oxygen, $(\mathbf{b}, \mathbf{e}) \mathbf{p H}$, and $\mathbf{( c , f ) ~ N i t r a t e ~ i n ~ c o l o r . ~ A l l ~ d a t a ~ a r e ~ i n c l u d e d ~ i n ~ t o p ~ p a n e l s , ~ w h e r e a s ~ s e l e c t e d ~ d a t e s ~ w i t h ~ c o n t r a s t i n g ~}$ freshwater conditions are shown in bottom panels - the dates are (1) April 01, 2016, (2) November 01, 2017, (3) July 01, 2018, and (4) February 15, 2019.

and coastal ocean acidification (Wallace et al., 2014; Gledhill et al., 2015). In similar high-latitude regions, such as the west coast of Norway, the highest transports of dissolved organic carbon and nutrients occur during periods of high freshwater outflows (Frigstad et al., 2020). The subsurface layer of this system has been characterized with high salinity, low $\mathrm{O}_{2}$, and high ammonium values suggesting that processes such as organic matter remineralization (e.g., nitrate/nitrite reduction and/or dissimilatory nitrate reduction to ammonium) could be occurring below the upper fresher layer (Frigstad et al., 2020). Similar BGC processes are suggested in southeastern Greenland where high nutrient content and particulate organic carbon fluxes below the euphotic (and fresher) layer imply significant remineralization (Seifert et al., 2019). Our results regarding high (low) oxygen and low (high) nitrate concentrations at surface (subsurface) levels during the recorded pulses of freshwater suggest that autotrophic (remineralization) processes would dominate above (below) the pycnocline.

The largest freshwater inputs into the coastal ocean are linked to polar and subpolar regions, such as the coastal oceans of Alaska (Royer, 1982; Johnson et al., 1988), Greenland (Jones et al., 2008), and Norway (Mork, 1981). Little is known about buoyancy-driven currents and BGC variability associated with the freshwater influence off western Patagonia where river outflows provides about $27,800-33,500 \mathrm{~m}^{3} \mathrm{~s}^{-1}$ of freshwater into the coastal ocean (from $\sim 40$ to $56^{\circ} \mathrm{S}$ ), forming an extensive low-salinity tongue (Neshyba and Fonseca, 1980; Dávila et al., 2002; Saldías et al., 2019). The high freshwater outflows in the region modify the properties of subantarctic water (SAAW) in the surface layer (Figure 1), generating the Modified Subantarctic Water (MSAAW) (Silva et al., 1995; Sievers and Silva, 2008). T-S diagrams are presented in Figure 4 to clarify the BGC characteristics of the water masses. Thus, freshwater events with MSAAW off western Patagonia would be primarily characterized by medium-to-high oxygen ( $\left.>250 \mu \mathrm{mol} \mathrm{kg}{ }^{-1}\right)$, high $\mathrm{pH}(>8)$, and low-to-medium nitrate $\left(<10-15 \mu \mathrm{mol} \mathrm{kg}^{-1}\right)$ concentrations (Figures 4a-c). Note that warmer freshwater events present even lower nitrate $\left(<5 \mu \mathrm{mol} \mathrm{kg}{ }^{-1}\right.$; Figure $\left.4 \mathrm{c}\right)$. The presence of Equatorial Subsurface Water (ESSW), with high (low) salinity and nitrate (oxygen) [Figures 4d,f; profile (4)], can also be identified from the T-S diagrams but mainly during 2019 when the float drifted slightly north of Gulf of Penas (Figure 1). The high subsurface salinity pool was evident from January to July 2019, occupying a depth range of about 200-400 m (Figure 2b). This finding is consistent with previous information suggesting the region around the Gulf of Penas as the southern limit of the spreading of ESSW (Silva et al., 2009), which could penetrate partially into nearby channels and fjords, as suggested by Sievers and Silva (2008).

There are strong land-ocean hydrographic and BGC gradients in fjords and channels of the Chilean Patagonia-inorganic nutrient concentrations present large spatial variability with nitrate (silicic acid) increasing (decreasing) from inland waters toward the Gulf of Penas (González et al., 2013). However, high vertical carbon flux and elevated sinking would avoid exporting a large fraction of materials into the coastal ocean (González et al., 2013). The freshwater outflows from nearby fjords and channels modify coastal waters' physicochemical 
characteristics off central Patagonia in approximately the top 50 $\mathrm{m}$ (see Figures 3E,F). These low-salinity nitrate-deficient waters would affect this coastal system's primary productivity in a large coastal extension (Figure 1). The relatively higher surface $\mathrm{pH}$ conditions during freshwater events should also modify the rates of the biologically-modulated chemical processes. This limiting condition is exacerbated by the entry of warm brackish waters due to the effect of a sharp pycnocline hindering the upwelling of nutrient-rich waters. Nitrate has been recognized as a limiting nutrient in the surface waters of northern Patagonia (Iriarte et al., 2007). On the other hand, periods of low freshwater conditions would favor the upwelling of subsurface nutrientrich waters promoting phytoplankton blooms, sometimes of anomalous species as observed off Chiloé Island in summer 2016 (León-Muñoz et al., 2018). Although the freshwater tongues are less likely to influence the BGC properties of the upper boundary of the Antarctic Intermediate Waters (AAIW), which are located below SAAW at around 150-200 m depth off the Gulf of Penas (Silva et al., 2009), they undoubtedly represent a buoyant boundary decreasing air-sea fluxes to reach down in the water column.

Spatiotemporal variability of the $\mathrm{O}_{2}: \mathrm{NO}_{3}^{-}$ratio seems to be mainly modulated by both changes in the primary production at the surface $(\sim 100 \mathrm{~m}$ depth)-using Chl-a as a proxy of photosynthetic activity, and organic matter respiration below the mixed layer at the coast, and by physical mechanisms (e.g., horizontal transport and/or air-sea interaction) occurring offshore. The higher values of the $\mathrm{O}_{2}: \mathrm{NO}_{3}^{-}$ratio registered at the surface ( $>30.0$; Figure 2f) during periods of maximum Chla availability and higher water column stratification (Figure 2g), appears to be the result of in situ nitrate consumption and oxygen production by photosynthetic organisms when the float reached the area of freshwater influence. The tight coupling between nitrate consumption and chlorophyll increase at the surface is denoted in Figure 2g. This photoautotrophic activity is also evidenced by a marked increase in the $\mathrm{pH}$ (Figure 2d), caused by the assimilation of inorganic carbon. In contrast, the lower $\mathrm{O}_{2}: \mathrm{NO}_{3}^{-}$ratio $(\sim 5.0)$ observed onshore below the mixed layer (Figure 2f), seems to be the result of local organic matter remineralization, characterized by the return of inorganic nitrogen to the system while oxygen is consumed (Figures 2e,c). The expected input of $\mathrm{CO}_{2}$, as a result of this respiration process, reduces, in consequence, the $\mathrm{pH}$ (Figure 2d). Relative to the coastal zone, oceanic waters were characterized to be less productive, with reduced biologically-mediated oxygenconsuming processes at depth owing the more limited organic matter load. The slightly high $\mathrm{O}_{2}: \mathrm{NO}_{3}^{-}$values (over the expected Redfield ratio), registered at surface in this oceanic waters with minimal phototrophic activity, can probably be explained by the effect of air-sea gas exchange, which, in turn, is modulated by the degree of oxygen saturation of the seawater (Johnson, 2010). In this sense, coastal surface (subsurface) waters were oversaturated (undersaturated) in oxygen, as a clear signal of in situ oxygen produced (consumed) by photosynthesis (respiration); whereas offshore waters were closer to the equilibrium with the atmosphere (Supplementary Figure 2). Thus, the $\mathrm{O}_{2}: \mathrm{NO}_{3}^{-}$ratio observed offshore, suggests that the cycling of these elements, far from the freshwater influence, is less biologically controlled, and that their availability is principally modulated by the circulation and by the chemical characteristics of the SAAW and AAIW at surface and subsurface levels, respectively (Silva et al., 2009, and references therein).

Throughout the BGC-Argo float trajectory, there is a seasonal change in the trophic status as the float reached the freshwaterinfluenced coastal area. Relative to the time series analyzed, the first phytoplankton bloom (up to $1.5 \mathrm{mg}$ Chl-a $\mathrm{m}^{-3}$ ) occurred during austral fall (March-April 2017), supported likely by nutrients remineralized from the organic matter produced and accumulated during summer time. After an evident diminished

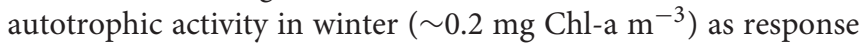
to the surface depletion of nutrients in the coastal zone (see Nitrate in Figure 2e), photosynthesis is reactivated in spring,

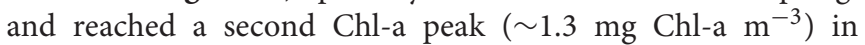
summer (November 2017) when light availability is greater in near-surface waters. This productive season is probably supported by the injection of subsurface nutrients that reach the upper layer by the end of winter, when the stratification is considerably reduced (Figures $\mathbf{2 a}-\mathbf{f}$ ). By the end of 2018, when the float returned onshore, the productive response of the system seems to be repeated: phototrophic activity began in spring (Chl-a slightly higher than $0.5 \mathrm{mg} \mathrm{m}^{-3}$ ), and was maximum by the end of summer ( $\sim 1.3 \mathrm{mg}$ Chl-a m${ }^{-3}$; April 2019). Interestingly, the BGC signal denotes the close coupling between surface and subsurface waters, considering that the biological material produced at the surface settles down and is respired at greater depths. Thus, the BGC variability off central Patagonia seems to be the result of a synergistic interaction between physical and biological processes, where stratification sets up the environment and facilitates the biological response that, in turn, is autoregulated by modifying the chemical composition and the availability of elemental components in the freshwater-influenced coastal area.

The arrival of new BGC Argo floats fully equipped (additional sensors of Chlorophyll, PAR, backscatter) to the region will provide new insights about the influence of freshening and freshwater stratification on BGC properties and their variability (e.g., chlorophyll fluctuations and trends, nitrogen and carbon cycling, and carbon sequestration, among others). Satellite fields of surface chlorophyll show that high phytoplankton biomass occurs mainly in spring-summer when the freshwater content off central Patagonia is the largest of its annual cycle (Saldías et al., 2019). However, the vertical structure and the depth of chlorophyll peaks related to the freshwater events are poorly understood. More extended time series will also add essential information on the freshening's interannual variability and its role in BGC processes considering the significant melting of Patagonian ice fields since 1968-1975 (Rignot et al., 2003). Finally, it is important to highlight that there may be deviations in BGC readings due to sensor drift (Johnson et al., 2017). Unfortunately, we do not have in situ measurements to evaluate how much variability could be due to a natural trend or a technical artifact. Johnson et al. (2017) found that sensor drift was constant throughout the water column. Hence, the potential impact of sensor drift in our measurements does 
not change our conclusions as, for example, the observed trend of nitrate at depth $(500 \mathrm{~m})$ is much lower than the variability of the upper layer where large BGC fluctuations occur (Supplementary Figure 3).

\section{DATA AVAILABILITY STATEMENT}

Publicly available datasets were analyzed in this study. The datasets analyzed for this study can be found in the Biogeochemical Argo Float website https://biogeochemicalargo.org/\# and HYCOM website https://www.hycom.org/ dataserver/gofs-3pt0/analysis/.

\section{AUTHOR CONTRIBUTIONS}

AG, GS, CL, and AC-A wrote the manuscript. RM and JI participated in discussions about the manuscript. JI revised the manuscript. GS, AC-A, and RM analyzed the data sets. All authors contributed to the article and approved the submitted version.

\section{FUNDING}

The primary funding source of this study was provided by FONDAP Research Center on Dynamics of High Latitude

\section{REFERENCES}

Adusumilli, S., Fricker, H. A., Medley, B., Padman, L., and Siegfried, M. R. (2020). Interannual variations in meltwater input to the Southern Ocean from Antarctic ice shelves. Nat. Geosci. 13, 616-620. doi: 10.1038/s41561-020-0616-Z Anderson, L. A. (1995). On the hydrogen and oxygen content of marine phytoplankton. Deep Sea Res. Part I: Oceanogr. Res. Pap. 42, 1675-1680. doi: 10.1016/0967-0637(95)00072-E

Bleck, R. (2002). An oceanic general circulation model framed in hybrid isopycnic-Cartesian coordinates. Ocean Model. 4, 55-88. doi: 10.1016/S1463-5003(01)00012-9

Bleck, R., and Boudra, D. B. (1981). Initial testing of a numerical ocean circulation model using a hybrid (quasi-isopycnic) vertical coordinate. J. Phys. Oceanogr. 11, 755-770. doi: 10.1175/1520-0485(1981)011<0755:ITOANO >2.0.CO;2

Boss, E., and Behrenfeld, M. (2010). In situ evaluation of the initiation of the North Atlantic phytoplankton bloom. Geophys. Res. Lett. 37, 1-5. doi: $10.1029 / 2010 \mathrm{gl} 044174$

Claustre, H., Johnson, K. S., and Takeshita, Y. (2020). Observing the global ocean with biogeochemical-argo. Annu. Rev. Mar. Sci. 12, 23-48. doi: 10.1146/annurev-marine-010419-010956

Corredor-Acosta, A., Morales, C. E., Brewin, R. J., Auger, P.-A., Pizarro, O., Hormazabal, S., et al. (2018). Phytoplankton size structure in association with mesoscale eddies off central-southern Chile: the satellite application of a phytoplankton size-class model. Remote Sens. 10:834. doi: 10.3390/rs10060834

Dávila, P. M., Figueroa, D., and Müller, E. (2002). Freshwater input into the coastal ocean and its relation with the salinity distribution off austral Chile $\left(35-55^{\circ} \mathrm{S}\right)$. Contin. Shelf Res. 22, 521-534. doi: 10.1016/S0278-4343(01)00072-3

Frigstad, H., Kaste, Ø., Deininger, A., Kvalsund, K., Christensen, G., Bellerby, R. G., et al. (2020). Influence of riverine input on Norwegian coastal systems. Front. Mar. Sci. 7:332. doi: 10.3389/fmars.2020.00332

Gledhill, D. K., White, M. M., Salisbury, J., Thomas, H., Mlsna, I., Liebman, M., et al. (2015). Ocean and coastal acidification off New England and Nova Scotia. Oceanography 28, 182-197. doi: 10.5670/oceanog.2015.41
Marine Ecosystems (IDEAL; Program 15150003). FONDAP IDEAL has fully supported AC-A. CL has been partially funded by FONDECYT 11090209 and the Millenium Nucleus Understanding Past coastal upWelling system and Environmental Local and Lasting impacts (UPWELL; NCN19_153). GS has been partially funded by ANIDMillennium Science Initiative Program-Code ICN2019_015 (Coastal Social-Ecological Millennium Institute, SECOS) and FONDECYT grant 1190805. AG has been funded by Vicerrectoría de Investigación y Postgrado, Universidad Católica del Maule.

\section{ACKNOWLEDGMENTS}

These data were collected and made freely available by the Coriolis project and programmes that contribute to it (http:// www.coriolis.eu.org). We thank to two reviewers for providing constructive comments that improved the original version of the manuscript.

\section{SUPPLEMENTARY MATERIAL}

The Supplementary Material for this article can be found online at: https://www.frontiersin.org/articles/10.3389/fmars. 2021.613265/full\#supplementary-material

González, H. E., Castro, L. R., Daneri, G., Iriarte, J. L., Silva, N., Tapia, F. J., et al. (2013). Land-ocean gradient in haline stratification and its effects on plankton dynamics and trophic carbon fluxes in Chilean Patagonian fjords (47-50 ${ }^{\circ} \mathrm{S}$ ). Prog. Oceanogr. 119, 32-47. doi: 10.1016/j.pocean.2013.06.003

Gould, J., Roemmich, D., Wijffels, S., Freeland, H., Ignaszewsky, M., Jianping, X., et al. (2004). Argo profiling floats bring new era of in situ ocean observations. Eos Trans. Am. Geophys. Union 85, 185-191. doi: 10.1029/2004EO190002

Gray, A. R., Johnson, K. S., Bushinsky, S. M., Riser, S. C., Russell, J. L., Talley, L. D., et al. (2018). Autonomous biogeochemical floats detect significant carbon dioxide outgassing in the high-latitude southern ocean. Geophys. Res. Lett. 45, 9049-9057. doi: 10.1029/2018GL078013

Iriarte, J., León-Mu noz, J., Marcé, R., Clément, A., and Lara, C. (2017). Influence of seasonal freshwater streamflow regimes on phytoplankton blooms in a patagonian fjord. N. Z. J. Mar. Freshw. Res. 51, 304-315. doi: 10.1080/00288330.2016.1220955

Iriarte, J. L., González, H. E., Liu, K. K., Rivas, C., and Valenzuela, C. (2007). Spatial and temporal variability of chlorophyll and primary productivity in surface waters of southern Chile (41.5-43 ${ }^{\circ}$ S). Estuar. Coast. Shelf Sci. 74, 471-480. doi: 10.1016/j.ecss.2007.05.015

Iriarte, J. L., Pantoja, S., and Daneri, G. (2014). Oceanographic processes in Chilean Fjords of Patagonia: from small to large-scale studies. Prog. Oceanogr. 129, 1-7. doi: 10.1016/j.pocean.2014.10.004

Jacob, B., Tapia, F. J., Daneri, G., Iriarte, J. L., Montero, P., Sobarzo, M. A., et al. (2014). Springtime size-fractionated primary production across hydrographic and PAR-light gradients in Chilean Patagonia (41-50S). Prog. Oceanogr. 129, 75-84. doi: 10.1016/j.pocean.2014.08.003

Johnson, K. S. (2010). Simultaneous measurements of nitrate, oxygen, and carbon dioxide on oceanographic moorings: observing the redfield ratio in real time. Limnol. Oceanogr. 55, 615-627. doi: 10.4319/lo.2010.55.2.0615

Johnson, K. S., Plant, J. N., Coletti, L. J., Jannasch, H. W., Sakamoto, C. M., Riser, S. C., et al. (2017). Biogeochemical sensor performance in the SOCCOM profiling float array. J. Geophys. Res. 122, 6416-6436. doi: 10.1002/2017JC0 12838 
Johnson, W. R., Royer, T. C., and Luick, J. L. (1988). On the seasonal variability of the Alaska Coastal Current. J. Geophys. Res. 93, 12423-12437. doi: 10.1029/JC093iC10p12423

Jones, E., Anderson, L., Jutterström, S., and Swift, J. (2008). Sources and distribution of fresh water in the East Greenland Current. Prog. Oceanogr. 78, 37-44. doi: 10.1016/j.pocean.2007.06.003

Karl, D. M., Björkman, K. M., Dore, J. E., Fujieki, L., Hebel, D. V., Houlihan, T., et al. (2001). Ecological nitrogen-to-phosphorus stoichiometry at station aloha. Deep Sea Res. Part II Top. Stud. Oceanogr. 48, 1529-1566. doi: 10.1016/S0967-0645(00)00152-1

Klausmeier, C. A., Litchman, E., Daufresne, T., and Levin, S. A. (2004). Optimal nitrogen-to-phosphorus stoichiometry of phytoplankton. Nature 429, 171-174. doi: 10.1038 /nature02454

Lenton, T. M., and Watson, A. J. (2000). Redfield revisited: 1. regulation of nitrate, phosphate, and oxygen in the ocean. Glob. Biogeochem. Cycles 14, 225-248. doi: 10.1029/1999GB900065

León-Mu noz, J., Urbina, M. A., Garreaud, R., and Iriarte, J. L. (2018). Hydroclimatic conditions trigger record harmful algal bloom in western Patagonia (summer 2016). Sci. Rep. 8:1330. doi: 10.1038/s41598-018-19461-4

Li, B., Watanabe, Y., Hosoda, S., Sato, K., and Nakano, Y. (2019). Quasi-real-time and high-resolution spatiotemporal distribution of ocean anthropogenic $\mathrm{CO}_{2}$. Geophys. Res. Lett. 46, 4836-4843. doi: 10.1029/2018GL081639

Mork, M. (1981). Circulation phenomena and frontal dynamics of the Norwegian Coastal Current. Philos. Trans. R. Soc. Lond. Ser. A Math. Phys. Sci. 635-647. doi: 10.1098/rsta.1981.0188

Munk, W. (2003). Ocean freshening, sea level rising. Science 300, 2041-2043. doi: 10.1126/science.1085534

Nerem, R. S., Beckley, B. D., Fasullo, J. T., Hamlington, B. D., Masters, D., and Mitchum, G. T. (2018). Climate-change-driven accelerated sea-level rise detected in the altimeter era. Proc. Natl. Acad. Sci. U.S.A. 115, 2022-2025. doi: $10.1073 /$ pnas.1717312115

Neshyba, S., and Fonseca, T. R. (1980). Evidence for counterflow to the west wind drift off South America. J. Geophys. Res. 85, 4888-4892. doi: 10.1029/JC085iC09p04888

Pantoja, S., Iriarte, J. L., and Daneri, G. (2011). Oceanography of the Chilean Patagonia. Contin. Shelf Res. 31, 149-153. doi: 10.1016/j.csr.2010.10.013

Rignot, E., Rivera, A., and Casassa, G. (2003). Contribution of the Patagonia Icefields of South America to sea level rise. Science 302, 434-437. doi: 10.1126/science.1087393

Riser, S. C., Freeland, H. J., Roemmich, D., Wijffels, S., Troisi, A., Belbéoch, M., et al. (2016). Fifteen years of ocean observations with the global Argo array. Nat. Clim. Change 6, 145-153. doi: 10.1038/nclimate2872

Roemmich, D., Alford, M. H., Claustre, H., Johnson, K. S., King, B., Moum, J., et al. (2019). On the future of Argo: a global, full-depth, multi-disciplinary array. Front. Mar. Sci. 6:439. doi: 10.3389/fmars.2019.00439

Roemmich, D., Johnson, G. C., Riser, S., Davis, R., Gilson, J., Owens, W. B., et al. (2009). The argo program: observing the global ocean with profiling floats. Oceanography 22, 34-43. doi: 10.5670/oceanog.2009.36

Royer, T. C. (1982). Coastal fresh water discharge in the northeast Pacific. J. Geophys. Res. 87, 2017-2021. doi: 10.1029/JC087iC03p02017
Saldías, G. S., Sobarzo, M., and Qui nones, R. (2019). Freshwater structure and its seasonal variability off western Patagonia. Prog. Oceanogr. 174, 143-153. doi: 10.1016/j.pocean.2018.10.014

Seifert, M., Hoppema, M., Burau, C., Elmer, C., Friedrichs, A., Geuer, J. K., et al. (2019). Influence of glacial meltwater on summer biogeochemical cycles in Scoresby Sund, East Greenland. Front. Mar. Sci. 6:412. doi: $10.3389 /$ fmars.2019.00412

Sievers, H., and Silva, N. (2008). "Water masses and circulation in austral Chilean channels and fjords," in Progress in the Oceanographic Knowledge of Chilean Interior Waters, From Puerto Montt to Cape Horn, eds N. Silva and S. Palma (Valparaíso: Comité Oceanográfico Nacional - Pontificia Universidad Católica de Valparaíso), 53-58.

Silva, N., Rojas, N., and Fedele, A. (2009). Water masses in the Humboldt Current System: properties, distribution, and the nitrate deficit as a chemical water mass tracer for Equatorial Subsurface Water off Chile. Deep Sea Res. Part II 56, 1004-1020. doi: 10.1016/j.dsr2.2008.12.013

Silva, N., Sievers, H., and Prado, R. (1995). Características oceanográficas y una proposición de circulación para algunos canales Australes de Chile entre $41^{\circ} 20^{\prime}$ S y $46^{\circ} 40^{\prime}$ S. Rev. Biol. Mar. 30, 207-254.

Simpson, J., Crisp, D., and Hearn, C. (1981). The shelf-sea fronts: implications of their existence and behaviour. Philos. Trans. R. Soc. Lond. Ser. A 302, 531-546. doi: 10.1098/rsta.1981.0181

Sukigara, C., Suga, T., Saino, T., Toyama, K., Yanagimoto, D., Hanawa, K., et al. (2011). Biogeochemical evidence of large diapycnal diffusivity associated with the subtropical mode water of the North Pacific. J. Oceanogr. 67, 77-85. doi: 10.1007/s10872-011-0008-5

Vizcaíno, M., Mikolajewicz, U., Gröger, M., Maier-Reimer, E., Schurgers, G., and Winguth, A. M. (2008). Long-term ice sheet-climate interactions under anthropogenic greenhouse forcing simulated with a complex Earth System Model. Clim. Dyn. 31, 665-690. doi: 10.1007/s00382-0080369-7

Wallace, R. B., Baumann, H., Grear, J. S., Aller, R. C., and Gobler, C. J. (2014). Coastal ocean acidification: The other eutrophication problem. Estuar. Coast. Shelf Sci. 148, 1-13. doi: 10.1016/j.ecss.2014.05.027

Wong, A., Wijffels, S. E., Riser, S. C., Pouliquen, S., Hosoda, S., Roemmich, D., et al. (2020). Argo data 1999-2019: two million temperature-salinity profiles and subsurface velocity observations from a global array of profiling floats. Front. Mar. Sci. 7:700. doi: 10.3389/fmars.2020.00700

Conflict of Interest: The authors declare that the research was conducted in the absence of any commercial or financial relationships that could be construed as a potential conflict of interest.

Copyright (C) 2021 Galán, Saldías, Corredor-Acosta, Muñoz, Lara and Iriarte. This is an open-access article distributed under the terms of the Creative Commons Attribution License (CC BY). The use, distribution or reproduction in other forums is permitted, provided the original author(s) and the copyright owner(s) are credited and that the original publication in this journal is cited, in accordance with accepted academic practice. No use, distribution or reproduction is permitted which does not comply with these terms. 